\title{
CHANGES IN CONSUMER'S BEHAVIOR OF HOUSEHOLDS IN THE VISEGRAD FOUR COUNTRIES IN THE PERIOD BETWEEN 2007 AND 2009
}

\author{
D. Skálová, J. Stávková
}

Received: November 30, 2011

\begin{abstract}
SKÁLOVÁ, D., STÁVKOVÁ, J.: Changes in consumer's behavior of households in the Visegrad four countries in the period between 2007 and 2009. Acta univ. agric. et silvic. Mendel. Brun., 2012, LX, No. 2, pp. 341-348

The onset of the economic crisis belongs to the years 2007 to 2009. This article evaluates the household consumption behaviour of European countries, especially in the Visegrad Four (V4), using consumption spending categories classified according to COICOP (Classification of Individual consumption by purpose) and using data available in the database of the European Commission, Eurostat. Available data include spending for the major commodities within the three years. The paper is devoted to the analysis of expenditure development, especially in the V4 countries and assesses whether there are any transfers of the shares between categories. The categories with the highest share of European household expenditures are: Food and non-alcoholic beverages, as well as Housing, water, gas and other fuels, transport. Furthermore, attention is concentrated, whether economic maturity of the V4 countries is reflected in the expenditure structure of selected countries. To search similarities in household consumption behaviour in EU countries, a cluster analysis is used. The results are shown in dendograms that help identify the differences among the individual EU states.
\end{abstract}

consumer behaviour, expenditure structure, household, crisis, the EU states, Visegrad group, cluster analysis

Consumer behaviour is related to consumption of tangible and intangible assets. This is not only about the behaviour associated with the immediate purchase of goods or services, nevertheless, searching for evaluation, selection and purchasing decision is part of it. Thanks to it a steady state is reached (Regnerová and Šálková, 2011).

From an economic point of view the result of rational considerations of consumers, eventually of households represents the consumer behaviour. The consumer decision is influenced by factors such as prices, incomes, demand functions, price elasticity of demand, budgetary constraints, utility etc. The major part of decision proceeds under uncertainty, because consumers and households have limited access and skills to process this information (Stávková et al., 2006).

Today's world requires the complex view on consumer behaviour. In terms of marketing on consumer behaviour, the individual approaches overlap, complement and by its combination results the consequent insight (Regnerová and Šálková, 2011).

It is common for people to say one thing, but to behave differently. This makes it difficult to understand why consumers behave in different ways, but it is more difficult to try to predict their behaviour. ${ }^{1}$ According to Dobřický (2003),

1 In: Consumer behaviour: The road to effective policy-making. 
consumer behaviour is a complicated process, which is influenced by many factors, in particular: the cultural, social, personal and psychological factor.

Consumer behaviour is dynamic, constantly evolving process that is not only when a customer trades money for goods or services. It is necessary to emphasize the consumption process, where is seen the influence on the customer both prior to purchase, during and after its realization. ${ }^{2}$ Studying the consumer behaviour is a means to understand and predict not only what consumer purchases, but also why, when, where and how often it happens (Schiffman, Kanuk; 2004).

Consumer behaviour is influenced by many factors. These factors have usually long-term effect and it is extremely difficult to identify those that lead to changes in consumer behaviour. Stávková, Stejskal, Toufarová (2008) analysed the factors that most influence the change in consumer behaviour.

\section{DATA AND METHODS}

The main source of secondary data, which are used for investigation related to the structure of household spending in selected EU states, are provided by the Statistical Office of the European Commission called EUROSTAT. In this study, data in percentage formulation are used, which convey the information of household spending in selected EU countries for individual items according to the COICOP (Classification of Individual Consumption by Purpose).

Data are available on the website of EUROSTAT. Due to this classification the gathered data are comparable to each other. Individual items by COICOP are listed in Tab. I.

For evaluation of secondary data the selected statistical methods are used. These are processed by the program STATISTICA CZ $8^{\text {th }}$. Besides the percentage of share and basic statistical methods a cluster analysis is also performed, which represents the multivariate statistical methods.

I: Classification of Individual Consumption by Purpose (COICOP/HICPs)

\begin{tabular}{|c|c|}
\hline $\begin{array}{l}\text { FOOD AND NON-ALCOHOLIC } \\
\text { BEVERAGES }\end{array}$ & $\begin{array}{l}\text { bread and cereals, meat, fish, milk, cheese and eggs, fruit, potatoes, vegetables, } \\
\text { sugar, jam, honey, chocolate and confectionery, food products, coffee, tea } \\
\text { and cocoa for consumption at home, mineral waters, soft drinks, fruit and } \\
\text { vegetable juices, non-alcoholic beverages }\end{array}$ \\
\hline $\begin{array}{l}\text { ALCOHOLIC BEVERAGES, } \\
\text { TOBACCO AND NARCOTICS }\end{array}$ & $\begin{array}{l}\text { spirits, wine, beer, alcoholic beverages for consumption at home, tobacco, } \\
\text { narcotics }\end{array}$ \\
\hline CLOTHING AND FOOTWEAR & $\begin{array}{l}\text { clothing materials, garments, other articles of clothing and clothing } \\
\text { accessories, cleaning, repair and hire of clothing, shoes and other footwear, } \\
\text { repair and hire of footwear }\end{array}$ \\
\hline $\begin{array}{l}\text { HOUSING, WATER, ELECTRICITY, } \\
\text { GAS AND OTHER FUELS }\end{array}$ & $\begin{array}{l}\text { rentals for housing, maintenance and repair of the dwelling, water supply and } \\
\text { miscellaneous services relating to the dwelling, electricity, gas and other fuels }\end{array}$ \\
\hline $\begin{array}{l}\text { FURNISHINGS, HOUSEHOLD } \\
\text { EQUIPMENT AND ROUTINE } \\
\text { MAINTENANCE OF THE HOUSE }\end{array}$ & $\begin{array}{l}\text { furniture, furnishings, carpets and other floor coverings, household textiles, } \\
\text { household appliances, glassware, tableware and household utensils, tools and } \\
\text { equipment for house and garden, goods and services for routine household } \\
\text { maintenance }\end{array}$ \\
\hline TRANSPORT & $\begin{array}{l}\text { purchase of vehicles, operation of personal transport equipment, transport } \\
\text { services }\end{array}$ \\
\hline COMMUNICATIONS & postal services, telephone and telefax equipment and services, \\
\hline RECREATION AND CULTURE & $\begin{array}{l}\text { audio-visual, photographic and information processing equipment, other } \\
\text { major durables for recreation and culture, other recreational items and } \\
\text { equipment; gardens and pets, recreational and cultural services, newspapers, } \\
\text { books and stationery, holidays }\end{array}$ \\
\hline EDUCATION & $\begin{array}{l}\text { pre-primary and primary education, secondary education, post-secondary } \\
\text { non-tertiary education, tertiary education, education not definable by level }\end{array}$ \\
\hline
\end{tabular}

Source: EUROSTAT, modified

2 In: Solomon, M., Consumer behavior: buying having and being, 2006. 


\section{RESULTS}

Data obtained from the database of the Statistical Office of the European Commission, Eurostat describe household consumption spending in individual EU countries and the composition of the items by COICOP classification. Description of individual items is shown above in Table I. The data were adjusted and ready for comparison in 2007, 2008 and 2009. It is therefore a period of global economic recession. To remove the effects of inflation and to ensure comparability of data across the individual states of EU 27, Harmonised Indices of Consumer Prices (HICPs) are applied.

Great Britain, Germany, France and Italy contributed the most to the total consumption spending of the EU 27 in 2007. The sum of consumption spending of these countries represents more than two thirds of EU-27 expenditures $(69.1 \%$ exactly). The same happened in 2008 and 2009. The states of the Visegrad Group (Czech Republic, Slovakia, Poland and Hungary), which we will focus on in the second part of the paper, were involved in consumer spending only by $4.2 \%$. In the following years the share of consumer spending of V4 grew slightly always by $1 \%$.

The size of national consumer spending is affected by population and economic maturity of the state. It is possible to observe a positive correlation between population and volume of state consumption spending (82.2 million inhabitants, Germany, Czech Republic 10.4 million inhabitants). Economic maturity is expressed using indicators of GDP per capita in purchasing power parity and relative to the mean of EU-27 (which is set to 100\%).

To analyse the structure of household consumption spending in EU member states, four important categories of expenditures were selected: food and non-alcoholic beverages, clothing and footwear, housing water, gas and other fuels, transport. Other category considers another eight items.

Countries are ranked in descending order according to expenditure on food and nonalcoholic beverages. In 2007 EU spent for these items in average $12.6 \%$. In the following years there was a slight increase in expenditure on these items (in 2008 by $0.4 \%$ in 2009 by another $0.1 \%$ ). It can be the first indicator of onset of the economic crisis, as households are forced to save on items that are necessary to ensure basic human needs.

The graph shows that the household spending on these items and economic maturity of countries has reciprocal proportion. The Member States which acceded in 2004 and 2007 are listed on the left to the EU average. These countries include also the states of the Visegrad Group. Within the V4, Poland has the largest expenditure on food and non-alcoholic beverages, at the same time Poland reaches the lowest economic development in a given year. On the contrary, the Czech Republic is the best because its spending on these items is the lowest and reaches the highest economic development. This fact has not changed even in 2008 when economic recession from USA penetrated into the European continent, even in 2009 when its consequences were shown.

EU-15, where is the superior economic welfare, are ranked on the right part of the graph, except for just Greece and Italy. Bulgaria must have been left out due to incomplete data.

Now we have an idea how the countries of V4 stand within the EU. Therefore we can precede to analysis the household consumption structure in these countries. The Graph 3 shows how are the individual items involved in the total household spending in the Czech Republic, Hungary, Slovak

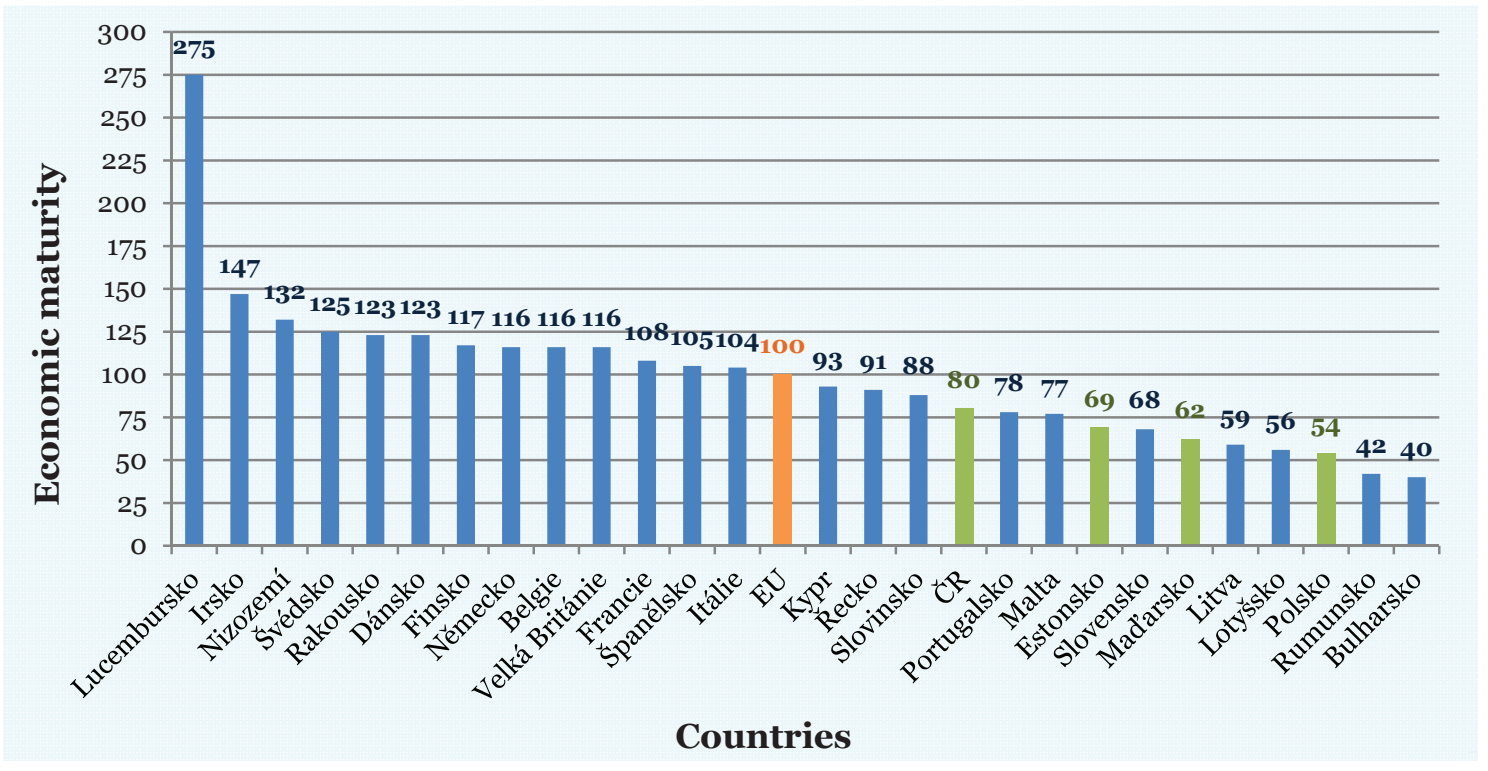

l: Economic maturity of EU-27countries in 2007

Source: EUROSTAT, modified 


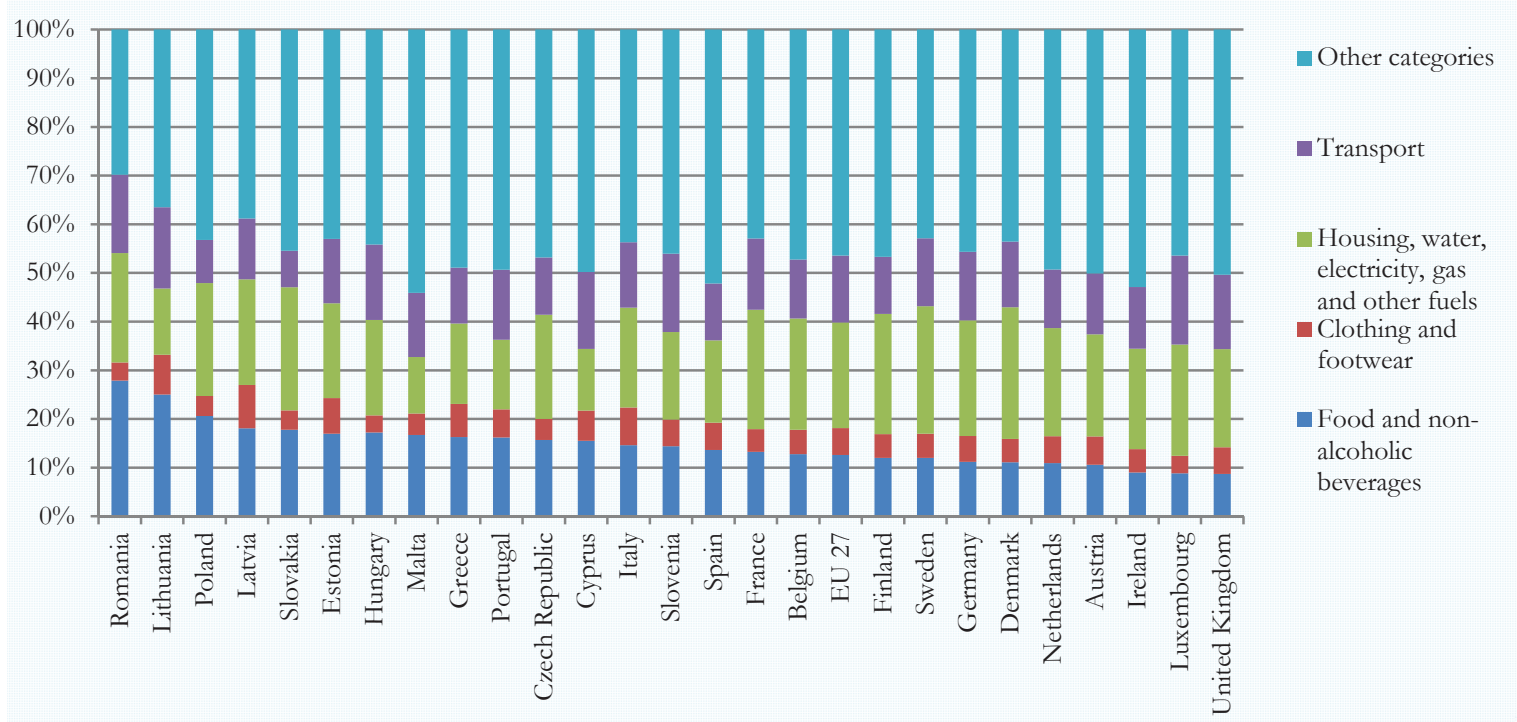

2: Structure of selected items of consumption spending of EU members in 2007 Source: EUROSTAT, adjusted

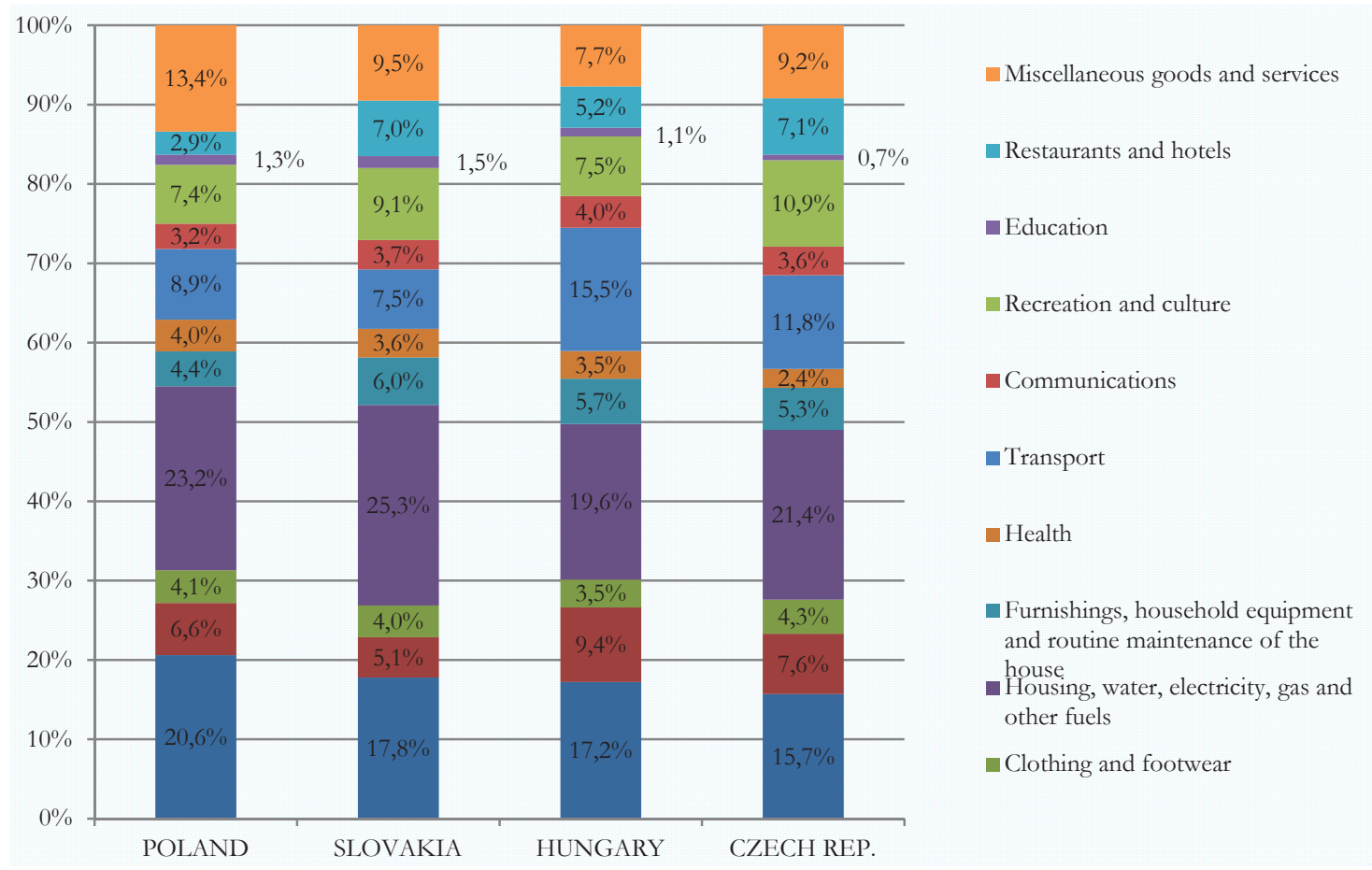

3: Structure of consumption spending in countries in 2007 Source: EUROSTAT, modified

Republic and Poland in 2007. The year 2007 can be taken as the reference year because rumours related to impending economic crisis were just transpired. According to the share of spending on basic categories, namely food and non-alcoholic beverages, housing, water, electricity, gas and other fuels, the economic position of the country can be deduced out of it. The results show that the weakest position occupies Poland, where households spend on food and non-alcoholic beverages $20.6 \%$ of total consumer spending, which is the most out of the V4 members. Expenditures on housing, water, electricity, gas and other fuels represent $23.2 \%$. On the contrary categories that satisfy higher needs, such as communication (3.2\%) or restaurants and hotels (2.9\%), have the smallest total consumer spending share of the V4 countries. This corresponds well with the economic maturity of Poland, which this year was the lowest of the V4 countries. The smallest share on the basic two 
categories has the Czech Republic, where the share on food and non-alcoholic beverages is $15.7 \%$ and is the smallest one in comparison with other members of V4. Hungary and Slovakia represent these expenditures $17.2 \%$, or $17.8 \%$ out of total household consumption spending.

The greatest item in the structure of household spending is expenditure on housing, water, electricity, gas and other fuels. On the contrary households invest the least in education, health, communications and restaurants and hotels.

The Tab. II shows the changes indices in individual items of household consumption spending between 2008 and 2009. Due to unavailability of data for Slovakia in 2009, there cannot be introduced change indices for 2009. The results show that during these two years, there has been some change in the structure of consumer spending and it is time to put this change at the expense of the economic crisis. In 2008, the changes were not evident, as the crisis had not bursted. However, it displayed in the structure of household consumption spending in the following year. There was decline in expenditure for clothing and footwear, transport, household equipment, communications, restaurants and hotels, and services. On the other hand the expenditures for housing, water, electricity, gas and other fuels and alcoholic beverages, tobacco and narcotics have arisen.

These changes are consistent with a significant decline in GDP and the decline of national economies in particular state of V4, which occurred during these two years. The largest decline in GDP was found in Slovakia, which decreased the growth rate of GDP between 2007 and 2009 by 15.3\%. GDP growth rate of the Czech Republic declined by 10.2\% in the same period and Hungary 7.5\%. Therein Poland turned preferably, a decrease of only $5.1 \%$.

Now we look at household consumer behaviour in EU countries, whether it is similar or not, eventually in which countries it is similar. For purposes of this article, attention will be devoted mainly to household consumption behaviour of V4. The indicators that affect the amount of money spent on household consumption are shown in Tab. I. To ensure comparability of data, percentage rate was used, which eliminates the influence of factors such as population or GDP. On the adjusted data a cluster analysis was applied and its main output is dendogram (Fig. 4, 5). It captures similarities in consumer behaviour in these countries in 2008 and 2009.

The process of cluster analysis for 2008 (Fig. 4) formed clusters, which connect the observed group of units with similar characteristics. Therefore, even though there are diverse countries, they are similar in terms of consumer behaviour, because there was created one cluster. This year the V4 countries joined one of the more significant clusters. Coherent group according to household consumption behaviour and expenditure on individual items is formed with Latvia, Estonia, Slovenia and Italy. The Czech Republic has the consumer level most similar to Slovakia. It forms a sub-cluster with Latvia and Poland, but the distance of joint is already larger. On the contrary, Hungary is on a separate branch of the sub-cluster and it can be stated that the household consumption behaviour is slightly different from the other V4 countries.

Another important sub-cluster consists of western (Belgium, Germany and France) and northern (Denmark, Finland and Sweden) European countries. It is an interesting finding, which confirms the living standard in individual countries. Great Britain, Ireland, Austria and the Netherlands have created sub-cluster, whose consumer behaviour has its own specifics, but not fundamentally different from the previous sub-cluster. Thus we may conclude that the consumption habits and patterns differ only little in the developed European countries.

This cannot be said of southern European countries - Greece, Spain, Cyprus and Malta, where the consumption habits and patterns substantially different from the rest of Europe. It is interesting that Italy has not joined them. Romania and Bulgaria are separate.

II: Changes in particular items of household consumption spending of V4 between 2008 and 2009 (2007=100)

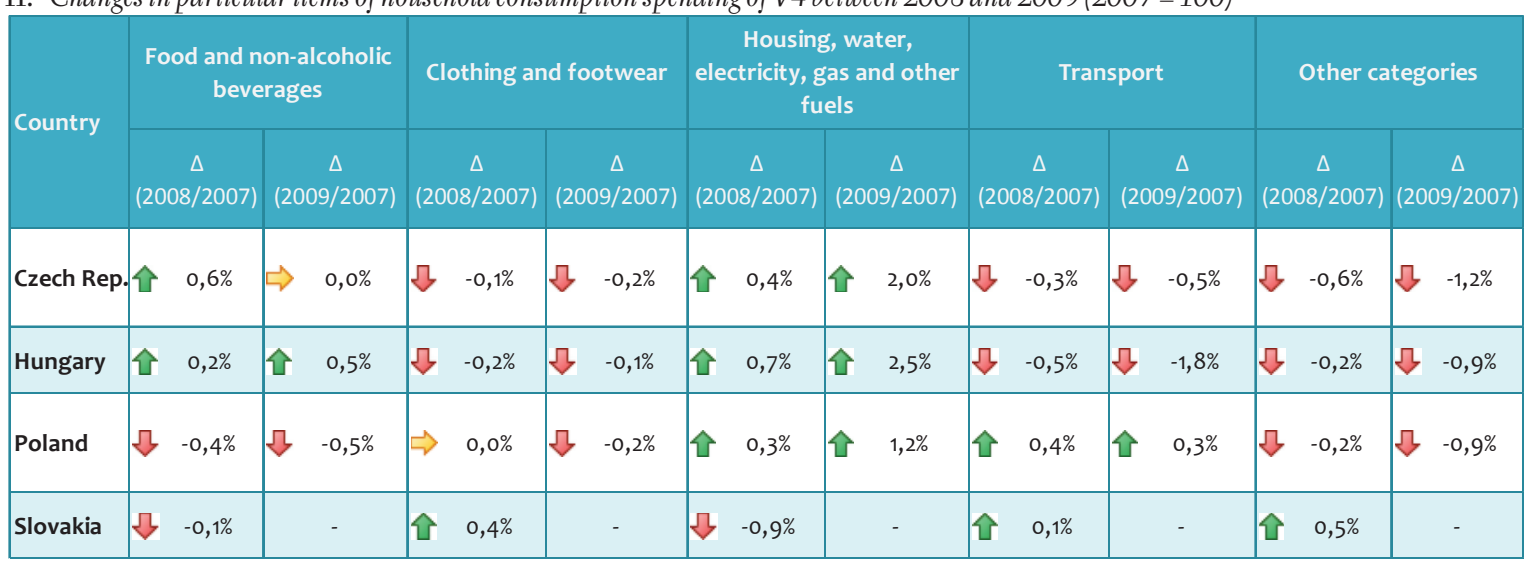

Source: EUROSTAT, modified 


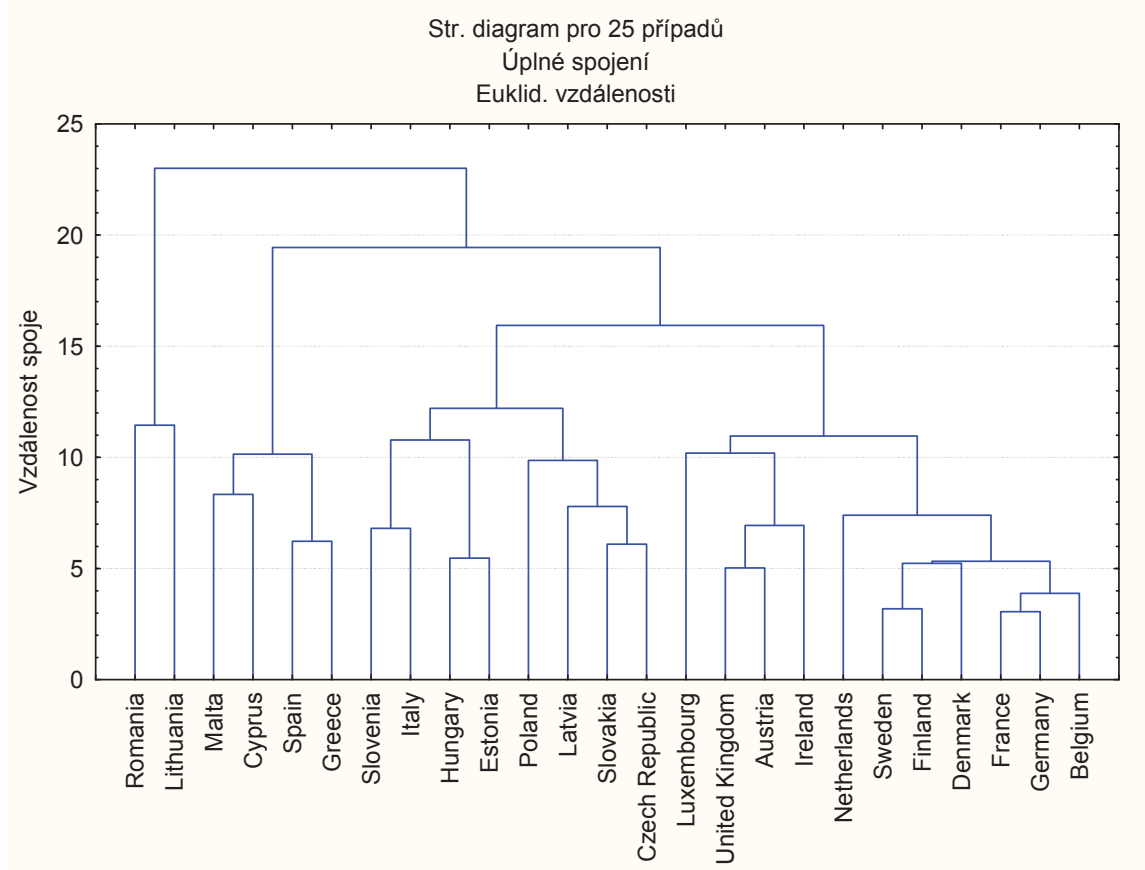

4: Dendogram of household consumption spending in the EU in 2008 Source: EUROSTAT, modified

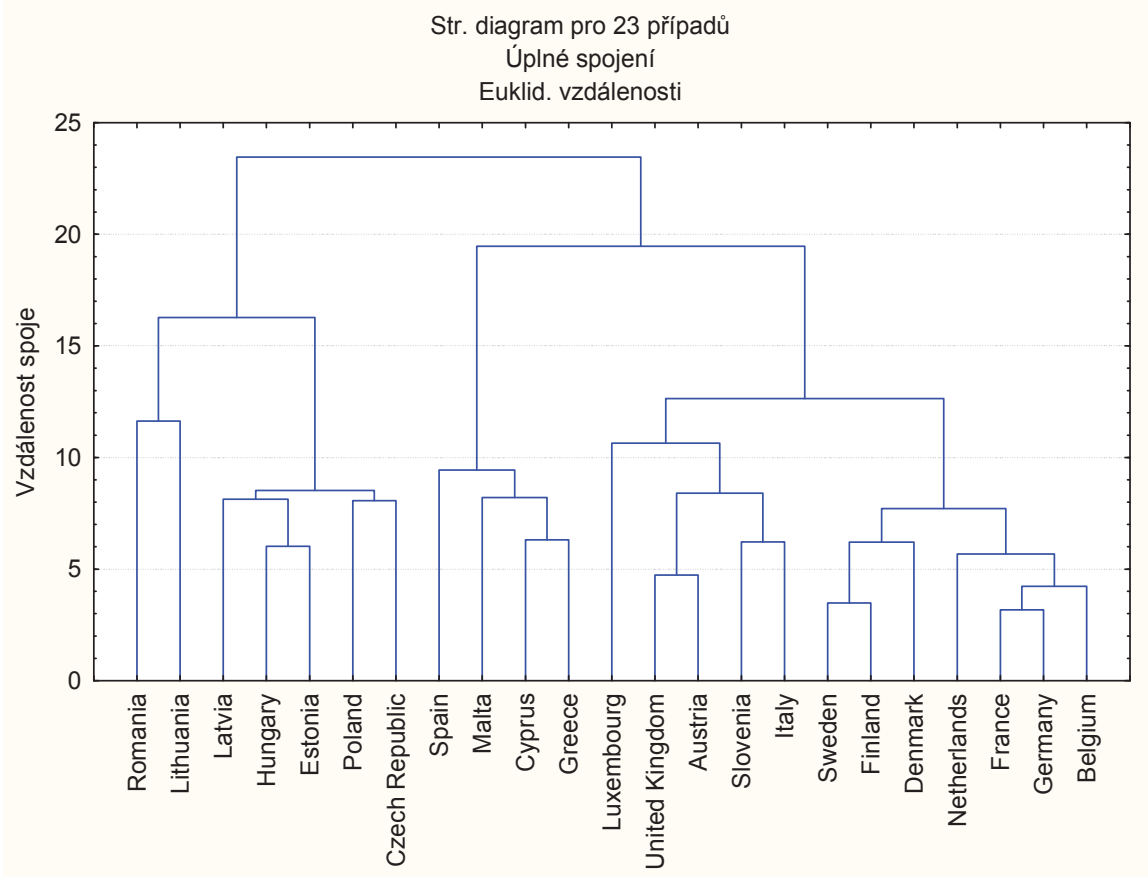

5: Dendogram of household consumption spending in the EU in 2009

Source: EUROSTAT, modified

In 2009 happened more significant reordering of individual clusters due to the economic crisis. You can identify two major clusters. The first cluster consists of the southern, western and northern Europe. However, the south-western states are a separate sub-cluster. Interesting is that household consumer behaviour came to approximation particularly in this regions.
On the contrary, the central European states joined the cluster with Bulgaria and Romania. V4 Countries again created sub-cluster, together with Estonia and Latvia. In this year the Czech Republic has the structure of consumer behaviour most similar to Poland, unlike the previous year. Consumer behaviour of Hungarian households is 
very similar to Estonia and Latvia. There were no data available for Slovakia for this year and therefore it does not appear in this sub-cluster.

It is not easy to clearly identify factors that shape and influence household consumer behaviour. Besides the cultural, social, personal and psychological factors, a microeconomic and a macroeconomic variable play an important role at household decisions, precisely how their money will be spent. We can mention for example prices of goods and services, utility or budget constraints of households. It directly affects consumer demand. The volume of available household resources, for which they can buy individual items, certainly depends on the current state of the economy, inflation and unemployment.

\section{SUMMARY}

The structure of household consumption behaviour of V4 states, the Czech Republic, Slovakia, Poland and Hungary, was changed within the particular years.

It can be attributed to economic crisis. In 2008 the changes were not so obvious. Economic recession began to display in household consumption behaviour structure in the following year.

Expenditures for following items declined: clothing and footwear, transport, housing equipment, communications, restaurant and hotels and services. On the other hand following expenditures increased: housing, water, electricity, gas and other fuels, tobacco, alcoholic beverages and narcotics. Expenditures for housing, water, electricity, gas and other fuels form the greatest item in the structure of household consumption behaviour.

The results of cluster analysis, which are graphically demonstrated in dondograms, show the significant differences in consumer behaviour among the southern European states, western and northern European States in the particular years 2008 and 2009. The V4 states and Baltic States form one bigger cluster in both years; there occurred only reordering within the cluster. This reordering is again connected with the change of expenditure structure in existent states.

\section{Acknowledgements}

The results referred in the paper are part of the intern grant project 25/2011: "Structure of expenditures in states of the Visegra Four."

\section{REFERENCES}

REGNEROVÁ, M., ŠÁLKOVÁ, D., 2011: Globalization and its impact on consumer behaviour [online]. [cit.2011-01-10]. Available from www: http:// www.logistickymonitor.sk/en/images/prispevky/ regnerova-salkova.pdf.

STÁVKOVÁ, J. a kol., 2006.: Consumer behaviourtrends. Provozně ekonomická fakulta MZLU v Brně, 1. vyd. Brno: MSD. 115 s. ISBN 80-86633-59-4.

DOBŘICKÝ, J., 2003: Marketing, lst Edition Praha, spol Sting Publishers, 134 p. ISBN 80-86342-40-9.

MELICHAROVÁ, A., 2008: Metodology of postkeynesian economy in consumer theory. Mendelova zemědělská a lesnická univerzita v Brně, 139 s. Disertační práce.

SCHIFFMAN, L. G., KANUK, L. L., 2004: Consumer behaviour. 1. vyd. Brno: Computer Press, a.s., 633 s. ISBN 80-251-0094-4.
SOLOMON, M., BAMOSSY, G., ASKEGAARD, S., 2002: Consumer behavior: A European perspective. 2. vyd. Prentice-Hall, Inc., 630 s., ISBN 13: 976-0273-65182-6.

CONSUMER BEHAVIOUR: THE ROAD TO EFFECTIVE POLICY-MAKING: Available from www: http://ec.europa.eu/consumers/docs/ldgsanco-brochure-consumer-behaviour-final.pdf.

STÁVKOVÁ, J., SHARMA, S., 2005: Behaviour of consumers in EU countries. Acta univ. Agric. Et silvic. Mendel. Brun., LIII, No. 3, pp. 311-318.

EUROSTAT [online] Available from www: http:// epp.eurostat.ec.europa.eu

KELBEL, J, ŠILHÁN, D., 2011: Cluster analysis: [online]. [cit.2011-01-10]. Available from www: http://staff.utia.cas.cz/nagy/skola/Projekty/ Classification/ShlukovaAnalyza.pdf. 
